\title{
Fungal-Transformation of Surrogate Sulphides and Carbonaceous Matter in Refractory Gold Ores: Revisited*
}

\author{
${ }^{1}$ G. Ofori-Sarpong, ${ }^{2}$ D. K. Adjei and ${ }^{1}$ R. K. Amankwah ${ }^{1}$ \\ ${ }^{1}$ Minerals Engineering Department, University of Mines and Technology, Tarkwa, Ghana \\ ${ }^{2}$ Energy and Mineral Engineering Department, Pennsylvania State University, USA
}

Ofori-Sarpong, G., Adjei, D. K. and Amankwah, R. K. (2017), "Fungal-Transformation of Surrogate Sulphides and Carbonaceous Matter in Refractory Gold Ores: Revisited", Ghana Mining Journal, Vol. 17, No. 2, pp. 56 65 .

\begin{abstract}
In the recovery of gold from refractory gold ores, pretreatment is required to decompose sulphides and liberate occluded gold before cyanidation, and to deactivate carbonaceous matter and prevent it from adsorbing dissolved gold. Until the past three decades, most commercial pretreatment processes had been by abiotic means. Biological pretreatment methods on commercial basis is therefore a recent phenomenon, and several researches are underway to assess the ability of different biological agents in the breakdown of sulphur and carbonaceous matter (CM) in gold ores. This paper, which is a revisit of an earlier one, presents an overview of on-going research aimed at assessing the capability of the fungus, Phanerochaete chrysosporium, to degrade sulphides and CM. Surrogate carbonaceous materials (lignite, bituminous and anthracite coals) and pure sulphides (pyrite and arsenopyrite) were used to model the behavior of CM and sulphides in refractory gold ores. To monitor the extent of biotransformation, preg-robbing test was conducted on the as-received and treated CM, and sulphide sulphur in the residual sulphidic materials was also determined. From an initial preg-robbing effect of $125 \mu \mathrm{g}$ of gold per gram of CM, the ability of CM to preg-rob gold reduced by $70-95 \%$ in the order of lignite $<$ bituminous $<$ anthracite within 21 days of treatment, whereas there were $18 \%$ and $39 \%$ oxidation of sulphide sulphur in pyrite and arsenopyrite respectively. XRD examination of the treated anthracite confirmed reduction in the graphitic structure of carbon following fungal transformation. Similarly, there was a decline in the major sulphide peak after microbial pretreatment. The results indicate that the fungus biotransforms through destruction of the ordered structure, followed by introduction of oxygen groups. The amorphous nature, thus generated, inhibits the uptake of aurocyanide ions by CM, while enhancing the affinity of cyanide for the oxidised sulphide material in subsequent cyanidation treatment. The findings contribute to knowledge on novel and technically viable alternative methods for oxidative pretreatment of refractory gold ores.
\end{abstract}

Keywords: Phanerochaete Chrysosporium, Carbonaceous Matter, Metal Sulphides, Biotransformation

\section{Introduction}

\subsection{Gold Ores and Refractoriness}

Gold ores can be classified broadly as nonrefractory (alluvial and free-milling) and refractory from a metallurgical standpoint, depending on the mineralogy and the ease of gold extraction. In alluvial ores, gold exists as discrete particles naturally liberated by weathering, and may be recovered by scrubbing and concentration processes, where the high specific gravity of gold is exploited for separation. Free-milling ores are those from which about $95 \%$ of the gold can be recovered by gravity concentration and/or simple cyanidation after milling to $80 \%$ passing $75 \mu \mathrm{m}$ (Marsden and House, 2006).

Refractory gold ores are more difficult to treat, and depending on the degree of refractoriness, recovery could be below $50 \%$ (Vaughan, 2004). Since gold ores are fixed resources, the incessant mining and subsequent depletion of non-refractory gold ores continues to generate profound interest in research on gold recovery from refractory ores. These hardto-treat ores occur in several gold mining regions throughout the world, and production of gold from refractory ores continues to increase with time (Boyle, 1979; Brierley, 1997; Adam et al., 2017).

In refractory ores, gold usually exists as extremely fine particles (Marsden and House, 2006) in intimate association with gangue materials, making gold extraction by direct cyanidation and carbon adsorption processes inefficient and unattractive. The major problem of refractoriness centres on the presence of metal sulphides and/or carbonaceous matter (CM). In sulphidic refractory gold ores, tiny gold particles may be highly disseminated and locked up or occluded within the grain boundaries or fractures of sulphides, typically pyrite and arsenopyrite. For this reason, decomposition of the sulphides is required to liberate the gold for subsequent cyanidation (Boyle, 1979; Guay, 1981; Arriagada and Osseo-Asare, 1984; Ofori-Sarpong et al., 2011; 2013b; Adam et al., 2017). The presence of carbonaceous matter $(\mathrm{CM})$ in gold ores leads to two main deleterious effects: (a) confinement of gold with attendant difficult release from the CM matrix and (b) loss of dissolved metal via the ability of CM to adsorb gold from goldimpregnated solution (Afenya, 1991; Pyke et al., 1999; Helm et al., 2009; Ofori-Sarpong et al., 
2010; Yang et al., 2013; Liu et al., 2014). Unlike activated carbon, adsorption of gold by CM leads to gold losses as the fine particles escape the openings of the typical screens used in the leaching circuit, and this phenomenon is termed as pregrobbing (Osseo-Asare et al., 1984; Hausen and Bucknam, 1985). Preg-robbing of CM is generally investigated using various coal ranks as surrogates due to the similarities between $\mathrm{CM}$ and coal (Ibrado and Fuerstenau, 1992; Amankwah and Yen, 2006; Ofori-Sarpong et al., 2010).

\subsection{Pretreatment of Refractory Gold Ores}

For gold locked up in the refractory components, especially sulphides, to be amenable to cyanidation, pretreatment is required to decompose these shielding minerals, thus liberating the gold. The processes that have been used commercially to pretreat refractory gold ores include roasting, pressure oxidation and bacterial oxidation (Arriagada and Osseo-Asare, 1984; Berezowsky et al., 1988; Marsden and House, 2006). Roasting involves the use of high temperature $\left(450-750^{\circ} \mathrm{C}\right)$ to decompose sulphidic and carbonaceous materials in the presence of oxygen/air. The combustion reaction leads to generation of harmful gases such as sulphur dioxide and arsenic trioxide, which cause environmental problems if mishandled (Komnitsas and Pooley, 1989; Nyavor and Egiebor, 1992; Marsden and House, 2006). Pressure oxidation makes use of high temperature and pressure, typically $180-225^{\circ} \mathrm{C}$ and $1500-3200 \mathrm{kPa}$, to decompose metal sulphides in the presence of water. Though this process eliminates the harmful gaseous products, it is associated with operational difficulties such as safety due to high operating temperatures and pressures, higher rates of material corrosion, and higher equipment cost (Yannopoulos, 1991; Berezowsky et al., 1988; Marsden and House, 2006).

In view of the above, the use of biooxidation which can be seen as the biological counterpart of pressure oxidation has become more prominent for the past two decades. Biooxidation partly reduces the high cost associated with roasting, and generally improves upon gold recovery and environmental/safety aspects of processing (Brierley, 1997; Hackl, 1997; Rawlings, 1998; Marsden and House, 2006).

\subsubsection{Biooxidation of Sulphidic Gold Ores}

Several bacteria are known to oxidize sulphides but the ones commonly used in commercial biooxidation of refractory gold ores are Leptospirillum ferrooxidans, Acidithiobacillus caldus, Leptospirillum ferriphilum, Acidithiobacillus thiooxidans, Acidithiobacillus ferrooxidans and Sulfobacillus spp (Rawlings, 1998; Amankwah et al., 2005; Harneit et al., 2006). The bacteria catalyze the biooxidation reaction by oxidizing iron (II) and elemental sulphur respectively to iron (III) and sulphuric acid, which act as lixiviants for indirect oxidation of the sulphides (Holmes and Bonnefoy, 2006). The main reactions involved in pyrite oxidation can be summarized in Equations 1 to 5 (Bennett and Tributsch, 1978; Sand et al., 1995).

$$
\begin{aligned}
& 2 \mathrm{FeS}_{2}+7 \mathrm{O}_{2}+2 \mathrm{H}_{2} \mathrm{O} \longrightarrow 2 \mathrm{Fe}^{2+}+4 \mathrm{SO}_{4}^{2-}+4 \mathrm{H}^{+} \\
& 4 \mathrm{Fe}^{2+}+\mathrm{O}_{2}+4 \mathrm{H}^{+} \rightarrow 4 \mathrm{Fe}^{3+}+2 \mathrm{H}_{2} \mathrm{O} \\
& \mathrm{FeS}_{2}+14 \mathrm{Fe}^{3+}+8 \mathrm{H}_{2} \mathrm{O} \rightarrow 15 \mathrm{Fe}^{2+}+16 \mathrm{H}^{+}+2 \mathrm{SO}_{4}^{2-} \\
& \mathrm{FeS}_{2}+2 \mathrm{Fe}^{3+} \rightarrow 3 \mathrm{Fe}^{2+}+2 \mathrm{~S}^{0} \\
& 2 \mathrm{~S}^{0}+3 \mathrm{O}_{2}+2 \mathrm{H}_{2} \mathrm{O} \rightarrow 4 \mathrm{H}^{+}+2 \mathrm{SO}_{4}^{2-}
\end{aligned}
$$

Equation 1 is basically a chemical reaction, but it is reported to occur much faster in an environment of suitable bacteria whereas 2 and 5 do not proceed to any appreciable limit under atmospheric conditions and are said to rely entirely on bacterial catalysis. Though Equations 3 and 4 can proceed without microbial involvement, their products, $\mathrm{Fe}^{2+}$ and $\mathrm{S}^{0}$, have to be oxidised by the bacteria to regenerate the lixiviants for ongoing oxidation of pyrite (Rawlings et al, 2003; Holmes and Bonnefoy, 2006; Marsden and House, 2006).

At the end of biooxidation, gold may be totally liberated or associated with relatively more porous iron oxides, and thus amenable to cyanidation (Marsden and House, 2006). Unfortunately, because most of the major bacterial strains are autotrophs, and thus meet their carbon requirement by synthesizing carbon dioxide, they do not metabolise organic carbon in the ore (Silver, 1970; Madigan and Martinko, 2006; Ofori-Sarpong and Osseo-Asare, 2013). Consequently, CM, if present, is not degraded, and thus routed into downstream cyanidation circuits where it preg-robs dissolved gold (Amankwah et al., 2005; Ofori-Sarpong et al., 2013b; Adam et al., 2017).

\subsubsection{Biomodification of Carbonaceous Matter}

Apart from roasting that aims at eliminating the organic carbon, passivation has been employed using carbon-blanking agents such as kerosene and other organic reagents (Abotsi and Osseo-Asare, 1987; Hutchins et al., 1988; Adams and Burger, 1998). Though yet to be applied commercially, biomodification of carbonaceous matter appears more attractive from economical and environmental points of view, as it occurs at relatively low temperatures $\left(25-40{ }^{\circ} \mathrm{C}\right)$ and at atmospheric pressure. In addition, lixiviants are regenerated in situ due to the presence of microorganisms. Microorganisms employed in this manner include the bacteria; Pseudomonas sp., Achromobacter sp., Streptomyces setonii, and the 
fungi; Aspergillus bruneio, Penicillium citrinum, Trametes versicolor and Phanerochaete chrysosporium (Brierley and Kulpa, 1993; Amankwah and Yen, 2006; Yen et al., 2008; OforiSarpong et al., 2010; Konadu et al., 2016).

\subsection{Phanerochaete chrysosporium}

Phanerochaete chrysosporium is a white rot fungus which belongs to the basidiomycetous family; a family of filamentous fungi that exhibits mushroom-like growth with extensive network of cross-walled filaments (Madigan and Martinko, 2006; Ofori-Sarpong et al., 2013a). The filaments are able to penetrate wood and degrade lignin (the most recalcitrant component of wood) with the aim of getting access to cellulose and hemicellulose (Tien and Kirk, 1984), thus leaving specks of white delignified areas amidst thin areas of firm wood, a phenomenon referred to as 'white rotting'. The first lignin-degrading enzyme, lignin peroxidase (LiP), was isolated from $P$. chrysosporium, and characterized by Tien and Kirk (1984). The fungus has hence been studied as a model organism, since it grows quickly, degrades lignin rapidly, and has a relatively medium temperature optimum $\left(37-39{ }^{\circ} \mathrm{C}\right)$ and low $\mathrm{pH}$ optimum (3.5-4.5), though it can grow over a wider range of temperature and $\mathrm{pH}$ (OforiSarpong et al., 2010; 2011).

P. chrysosporium also secretes another enzyme, called manganese peroxidase $(\mathrm{MnP})$. The oxidative enzymes of the fungus catalyze the biodegradation of lignin and a variety of aromatic carbonaceous materials including low rank coals, wood chips and environmental pollutants (Glenn et al., 1983; Bumpus and Aust, 1986; Ralph and Catcheside, 1997; Tunde and Tien, 2000; Martin and Petersen, 2001). Carbonaceous matter (CM) in refractory gold ores is characterized to be similar to coal, and thus potential substrates for the fungus (OforiSarpong et al., 2013b).

Aside LiP and MnP, P. chrysosporium secretes a $\mathrm{H}_{2} \mathrm{O}_{2}$-generating enzyme, glyoxal oxidase (Kersten and Kirk, 1987), and hydrogen peroxide is known to solubilize pyrite and arsenopyrite as presented in Equations 6 and 7 (Antonijevic et al., 1997; Jennings et al., 2000). The iron (III) and sulphuric acid produced, constitute the reagents created by the sulphide-oxidising bacteria for the indirect biooxidation of sulphides ( Sand et al., 1995; Hackl, 1997; Holmes and Bonnefoy, 2006).

$$
2 \mathrm{FeS}_{2}+15 \mathrm{H}_{2} \mathrm{O}_{2} \rightarrow 2 \mathrm{Fe}^{3^{+}}+4 \mathrm{SO}_{4}{ }^{2-}+2 \mathrm{H}^{+}+14 \mathrm{H}_{2} \mathrm{O}
$$

$\mathrm{FeAsS}+7 \mathrm{H}_{2} \mathrm{O}_{2} \rightarrow \mathrm{Fe}^{3^{+}}+\mathrm{AsO}_{4}^{3-}+\mathrm{SO}_{4}{ }^{2-}+2 \mathrm{H}^{+}+6 \mathrm{H}_{2} \mathrm{O}$

The strong oxidizing environment produced by the oxidative enzymes of $P$. chrysosporium is also known to be responsible for the oxidative removal of sulphur from coal (Gonsalvesh et al., 2008). $P$. chrysosporium therefore has the potential to catalyze the biotransformation of carbonaceous matter and sulphides, and boost gold extraction in the subsequent cyanidation step (Ofori-Sarpong et al., 2010; 2011; 2013b; Liu et al., 2014; Konadu et al., 2016).

This paper presents a review of the authors' ongoing research that utilizes fungal-mediated processes to achieve decomposition of metal sulphides and deactivation of carbonaceous matter in refractory gold ores. Analysis of the data obtained from this study is a contribution to the pool of scientific knowledge regarding processing of refractory gold ores and hence is of immense benefit to academia. In addition, the results could find application in gold production communities.

\section{Resources and Methods Used}

\subsection{Materials}

Coal of various ranks was used as surrogate for carbonaceous matter whereas pure pyrite and arsenopyrite were used to represent sulphides in refractory gold ores. Pyrite and arsenopyrite samples were supplied by Ward's Natural Science Establishment in the USA. Coal (anthracite, bituminous, and lignite) samples were provided by the Coal Bank of the Earth and Mineral Science Energy Institute whereas fungal spores of $P$. chrysosporium ME446 were obtained from Prof. Ming Tien of the Department of Biochemistry and Molecular Biology, all of the Pennsylvania State University, USA. The sulphide and carbon materials were crushed and sieved to all passing $250 \mu \mathrm{m}$ before incubation. Standard gold solution $(50 \mathrm{mg} / \mathrm{L}$ in $1 \mathrm{~g} / \mathrm{L}$ sodium hydroxide and $0.5 \mathrm{~g} / \mathrm{L}$ sodium cyanide) was supplied by High Purity Standards, USA, and all other chemicals used were of reagent grade.

\subsection{Medium Preparation, Incubation and Harvesting of Treated Material}

The millet and wheat bran (MWB) medium was prepared by using $8 \mathrm{~g}$ millet plus $2 \mathrm{~g}$ wheat bran. Double-distilled (dd) $\mathrm{H}_{2} \mathrm{O}$ used for the incubation was buffered with succinic acid and the $\mathrm{pH}$ adjusted to 4 using sodium hydroxide. The medium was moistened with water in Erlenmeyer flasks, in the ratio of $1 \mathrm{~g}$ medium: $1 \mathrm{~mL}$ dd $\mathrm{H}_{2} \mathrm{O}$, and autoclaved at $121{ }^{\circ} \mathrm{C}$ for $30 \mathrm{~min}$. On cooling, the medium was inoculated with $1 \mathrm{~mL}$ of spore suspension of $P$. chrysosporium (made by suspending 1 vial of spores in $25 \mathrm{~mL}$ of $\mathrm{dd} \mathrm{H}_{2} \mathrm{O}$ ). The optical density of the cell suspension used for inoculation was 0.3 relative to water, as measured with a Pharmacia LKB Ultraspec II UV-visible spectrometer at $600 \mathrm{~nm}$. The samples were 
incubated in triplicates at $60 \%$ solids and $37{ }^{\circ} \mathrm{C}$ for up to 21 days (Ofori-Sarpong et al., 2010; 2011). Fig. 1 shows autoclaved MWB medium (a) and coal cultured with $P$. chrysosporium in MWB (Ofori-Sarpong et al., 2010).

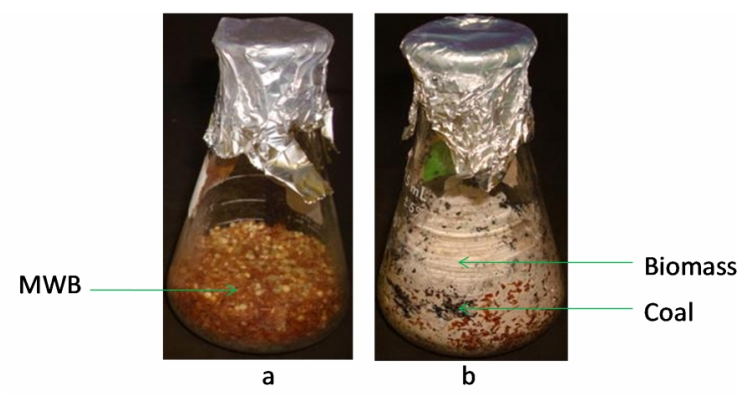

Fig. 1 Autoclaved MWB Medium (a) and Coal Cultured with $P$. chrysosporium in MWB (b) (After Ofori-Sarpong et al., 2010)

Control experiments were also set up for 3-14 days under similar conditions as described above, except that there was no addition of fungus. This was necessary to establish the exclusive effect of the fungus on biotransformation of sulphides and CM. At the end of the incubation period, the samples were washed with water in the ratio of about $1 \mathrm{~g}$ sample to $200 \mathrm{ml} \mathrm{H}_{2} \mathrm{O}$ to get rid of the media and fungal biomass, and then dried at $37^{\circ} \mathrm{C}$ for 7 days.

\subsection{Determination of the Extent of Biotransformation}

Various examinations were performed on the asreceived and treated carbonaceous and sulphidic materials to assess the extent of biotransformation. These include gold adsorption, sulphur speciation and $\mathrm{x}$-ray diffraction studies.

\subsubsection{Preg-robbing of Carbonaceous Materials}

Triplicate samples of biomodified, control and asreceived coals of various weights $(0.1 \mathrm{~g}-1 \mathrm{~g})$ were contacted with $25 \mathrm{~mL}$ of $5 \mathrm{mg} / \mathrm{L}$ gold solution at $\mathrm{pH} 11.5$ and agitated at $150 \mathrm{rpm}$ for 24 hours. At the end of the contact time, the residual solution was filtered, and gold in the filtrate, determined using Perkin-Elmer Optima 5300 inductively coupled plasma - atomic emission spectrometer (ICP-AES). The difference between the concentration of gold in solution before and after the adsorption test was computed with respect to the amount of carbon-containing material used for the adsorption, as shown in Equation 8, to obtain the Preg-robbing Effect of Carbon (PEC) in $\mathrm{g} / \mathrm{t}$.

PEC $\left(\right.$ in $\left.\frac{\text { gram of gold }}{\text { tonnes of carbon }}\right)=25 m L x\left(\left(I C_{A u}-F C_{A u}\right) \mu g / m L\right)\left(\frac{1}{W_{C} g}\right)$

In Equation 8, IC and $\mathrm{FC}$ are the initial and final concentrations of gold in solution, $\mathrm{W}_{\mathrm{C}}$ is the weight of carbonaceous material used in the adsorption test, and $25 \mathrm{~mL}$ is the volume of gold solution used. The difference in PEC values between asreceived and treated carbonaceous material gives an indication of the effect of fungalbiomodification on preg-robbing of gold by the carbon-containing materials.

\subsubsection{Sulphide Sulphur Oxidation in Sulphide Materials}

Sulphide sulphur in the residual sulphidic materials was determined in triplicates by the volumetric combustion technique using LECO Sulphur determinater SC-4444DR. These values compared with those obtained for the as-received gave the extent of biotransformation. Equation 9 depicts the Percentage Conversion of Sulphur (PCS) in the residual solids (Ofori-Sarpong et al., 2011), where $\mathrm{S}_{\mathrm{B}}$ and $\mathrm{S}_{\mathrm{A}}$ are respective sulphide sulfur contents before and after fungal treatment.

$$
\operatorname{PCS}(w t \%)=\frac{\left(S_{B}-S_{A}\right)(g)}{S_{B}(g)} \times 100 \%
$$

\subsubsection{X-ray Diffraction of Carbonaceous and Sulphidic Materials}

The XRD analysis was carried out using PANalytical X'Pert Pro powder diffractometer with $\mathrm{X}$ 'celerator detector. The samples were ground to fine powder in an agate mortar and then sprinkled on the surface of quartz zero-background sample holder. A Ni-filtered $\mathrm{CuK}_{\alpha}$ radiation produced at $45 \mathrm{KV}$ and $40 \mathrm{~mA}$ was used for the analysis. The scan was run at a scan speed of $2 \mathrm{deg} / \mathrm{min}$ from 20 to $34 \mathrm{deg}$ and 25 to $50 \mathrm{deg}$ 2-theta for anthracite and pyrite respectively. Data acquisition was done using MDI Jade 9 software.

\section{Results and Discussion}

This paper discusses the pretreatment of carbonaceous matter and sulphides generally associated with refractory gold ores. The transformation was done by incubating surrogate substrates with the fungus, Phanerochaete chrysosporium maintained on millet and wheat bran (MWB) medium. The results are presented and discussed in the ensuing sections.

\subsection{Fungal-transformation of Carbonaceous Matter}

Anthracite, bituminous, and lignite coals were used as surrogates to study the carbonaceous matter $(\mathrm{CM})$ in gold ores, and the extent of biotransformation was measured primarily by the reduction in the ability of these coals to adsorb aurocyanide complex. To measure the degree of reduction in gold adsorption, it was necessary to 
know the amount of gold that can be adsorbed by the various coals in their as-received states, and this is presented in Fig. 2. It is clear from the figure that only anthracite was able to adsorb a substantial amount of gold cyanide complex; about $750 \mathrm{~g} / \mathrm{t}$. In contrast, lignite and bituminous coals adsorbed less than $50 \mathrm{~g} / \mathrm{t}$, and this was attributed to their relatively immature nature (Ofori-Sarpong et al., 2010).

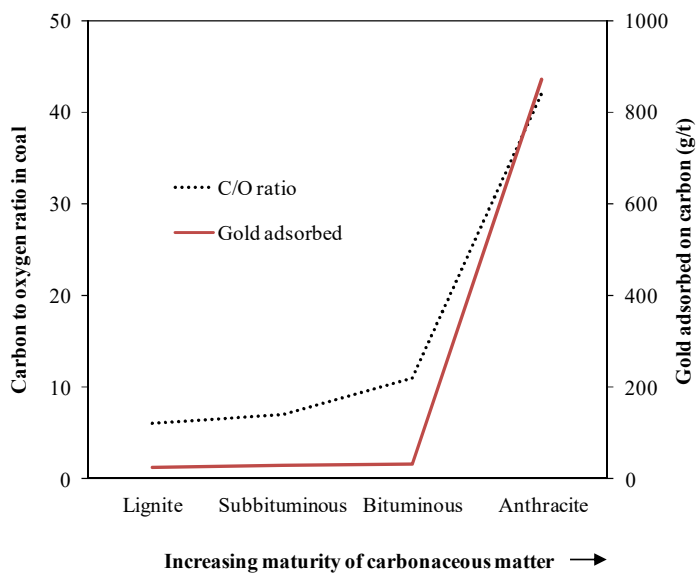

Fig. 2 Relationship of Coal Maturation to Gold Adsorption Ability

As coal matures from lignite to anthracite in the coalification process, there is cleavage of hydrogen and oxygen from the coal structure, leaving a skeletal carbon structure similar to that obtained in the production of activated carbon (Marsden and House, 2006). The maturity of coal is thus directly related to the degree of graphitization, which decreases in the order of anthracite $>$ bituminous $>$ sub-bituminous $>$ lignite, with a corresponding decrease in the carbon to oxygen ratio (Van Krevelen et al., 1993). The graphitic structure of carbon is known to be a major factor in the adsorption of gold cyanide onto carbon (Jones et al, 1989; Ibrado and Feurstenau, 1992; Helm et al., 2009; Amankwah and Yen, 2006; Ofori-Sarpong et al., 2010; 2013a). The preferential adsorption of gold cyanide on anthracite relative to the other coals is therefore due to better developed graphitic structure in anthracite. This is demonstrated in Fig. 2 , which relates the carbon to oxygen ratios in the various coal to their gold adsorption capacity. Correlating the carbon-to-oxygen ratios in various coals with gold adsorption, it was inferred by Ofori-Sarpong et al. (2010) that the adsorption of gold cyanide on anthracite is due to its high carbonto-oxygen ratio of about 42 compared to 5-11 for lignite, sub-bituminous and bituminous coals. Despite the relatively low degree of gold adsorption on the other coal ranks, Fig. 3 indicates that the ability to adsorb gold declined drastically for all the coals following fungal transformation. From an initial preg-robbing effect of $125 \mu \mathrm{g}$ of gold per gram of $\mathrm{CM}$, the ability of $\mathrm{CM}$ to preg-rob gold reduced by $70-95 \%$ in the order of lignite $<$ bituminous $<$ anthracite within 21 days of treatment. This is possibly due to relative gold adsorption abilities of the various coals in their asreceived states.

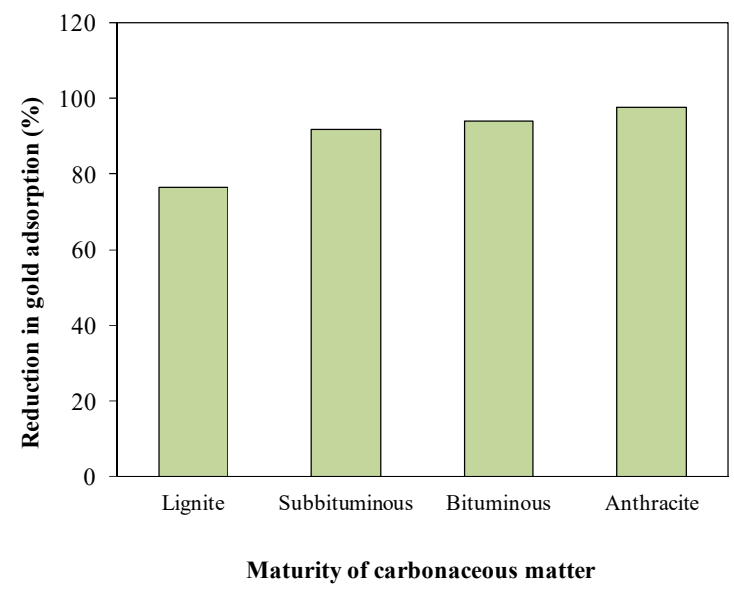

Fig. 3 Reduction in Gold Cyanide Adsorption on Biotransformed Coal

Since anthracite has the ability to adsorb more than 10 times that of the other coals, it was necessary to extend the investigation to cover other factors that may affect the degree of biotransformation of anthracite. The effect of fungal transformation time on gold adsorption as presented in Fig. 4, shows more than $90 \%$ decrease in preg-robbing after treatment for one week. Also, to demonstrate the exclusive effect of the fungus on the decline in gold adsorption by anthracite, control experiments were set up using the medium alone, and the result is depicted in Fig. 5.

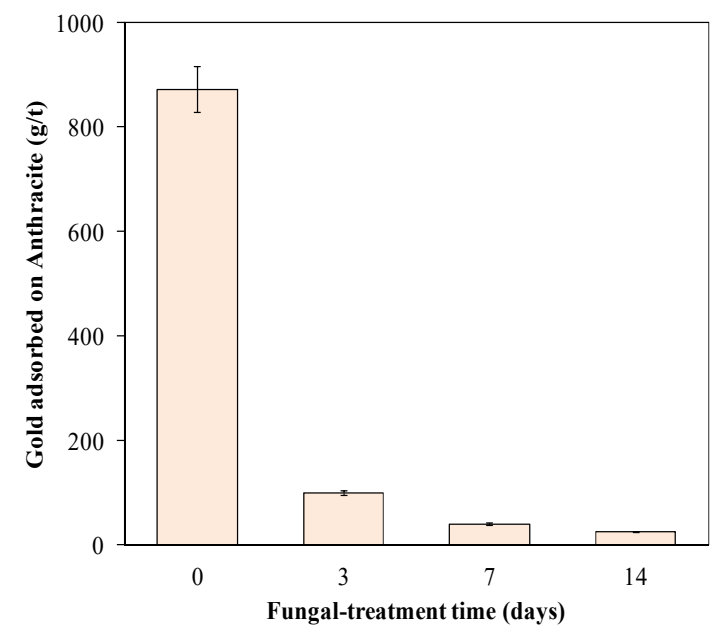

Fig. 4 Effect of Fungal Transformation Time on Gold Adsorption by Anthracite Coal 


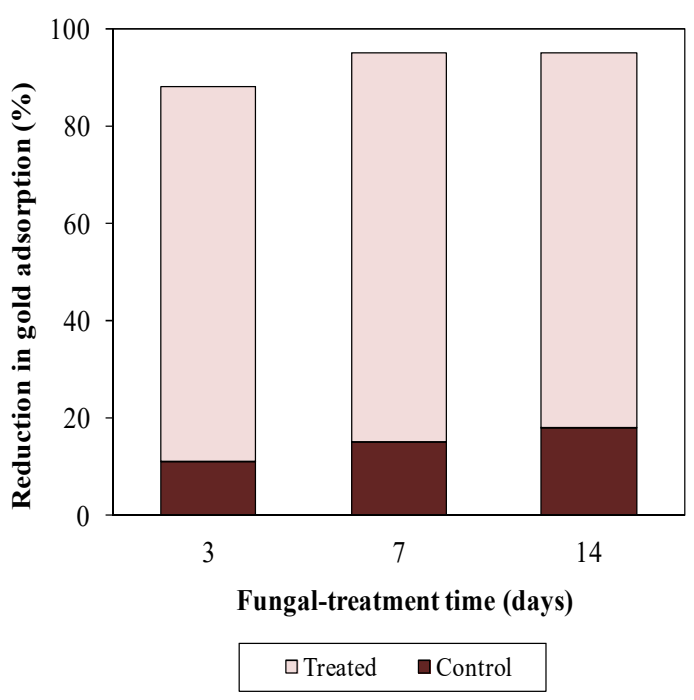

Fig. 5 The Exclusive Effect of $P$. chrysosporium on Biotransformation of Anthracite Coal

The lower portions of the bars represent percentages of the total transformation attributed to the medium alone whereas the upper portions show the additional reduction in preg-robbing capacity of anthracite, when the medium was cultured with $P$. chrysosporium. It is clear from the figure that, though the medium alone results in some blinding of adsorption sites (Ofori-Sarpong et al., 2010; $2013 \mathrm{a}$ ), the presence of the fungus imparts about $400 \%$ more deactivation on the carbonaceous matter.

Characterization of anthracite using XRD as shown in Fig. 6, indicates a great reduction in the graphite peak at $27 \mathrm{deg}$ on the 2-theta axis as a result of fungal-treatment. This peak is characteristic of very structured graphite. Thus a reduction in this peak indicates a decrease in the J-factor, which implies an increase in the degree of disorderliness/amorphousity (Gordon and Asiam, 2012) of the treated carbon relative to the asreceived. Since gold adsorption is reported to occur mostly on the graphitic planes (Ibrado and Fuerstenau, 1992), destruction of the graphitic structure followed by introduction of oxygen groups will disrupt the continuous planes required for gold cyanide adsorption, and this in part, explains the reduction in gold adsorption (OforSarpong et al., 2013a; Liu et al., 2014). In work done by Konadu et al. (2016) on biotransformation of powdered activated carbon (PAC) using enzymes of $P$. chrysosporium, the authors recorded a decrease of $57 \%$ in post-treatment gold adsorption. Futher characterization of the solid residues of $\mathrm{PAC}$ by ${ }^{13} \mathrm{C}$ NMR revealed a decomposition of polyaromatic into aliphatic carbons, whereas the specific surface area also reduced by roughly $50 \%$.

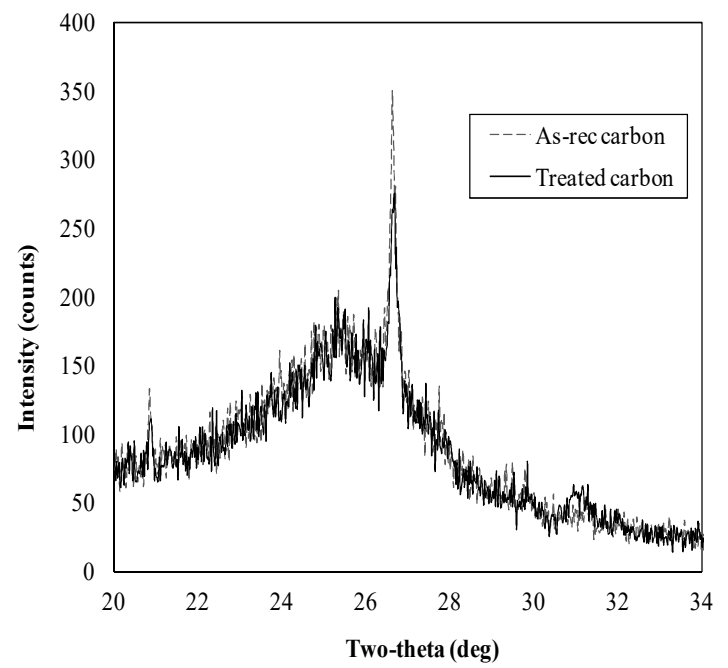

Fig. 6 X-ray Diffraction of Anthracite Coal before and after Fungal-treatment

\subsection{Fungal-transformation of Metal Sulphides}

The forms of sulphur in sulphur compounds are generally classified into sulphide sulphur, elemental sulphur and sulphate sulphur, with oxidation states of $-2,0$ and +6 respectively. Sulphide (pyritic) sulphur, being the most reduced form, may be oxidised into several forms such as elemental sulphur, dithionate, thiosulphate and sulphate, some of which are unstable and may further transform into other products. The transformaton of sulphides may thus be monitored by the reduction in concentration of sulphide sulphur in the parent material. The transformation of pyrite and arsenopyrite were measured using the LECO sulphur titrator, and the resulting sulphide sulphur oxidation are depicted in Figs. 7 and 8 respectively, whereas Fig. 9 compares the control experiment with the fungal-treatment after a 2week contact time.

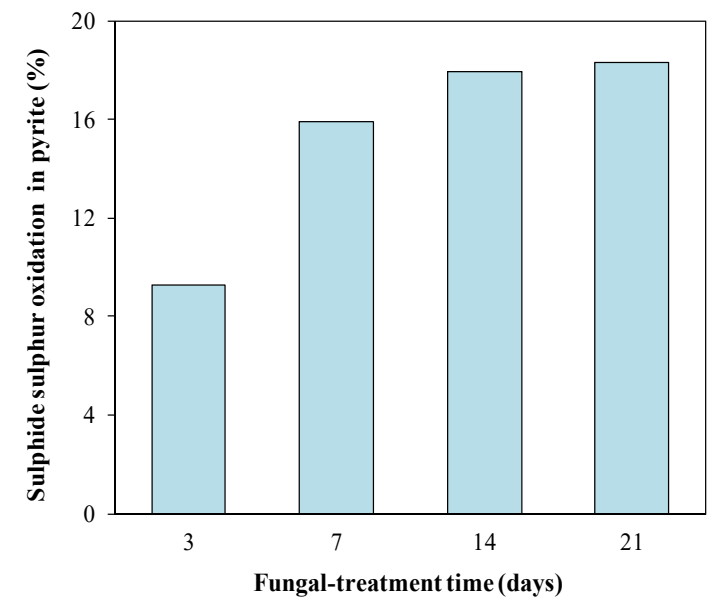

Fig. 7 Oxidation of Sulphide Sulphur in Pyrite following Pretreatment with $\boldsymbol{P}$. chrysosporium 


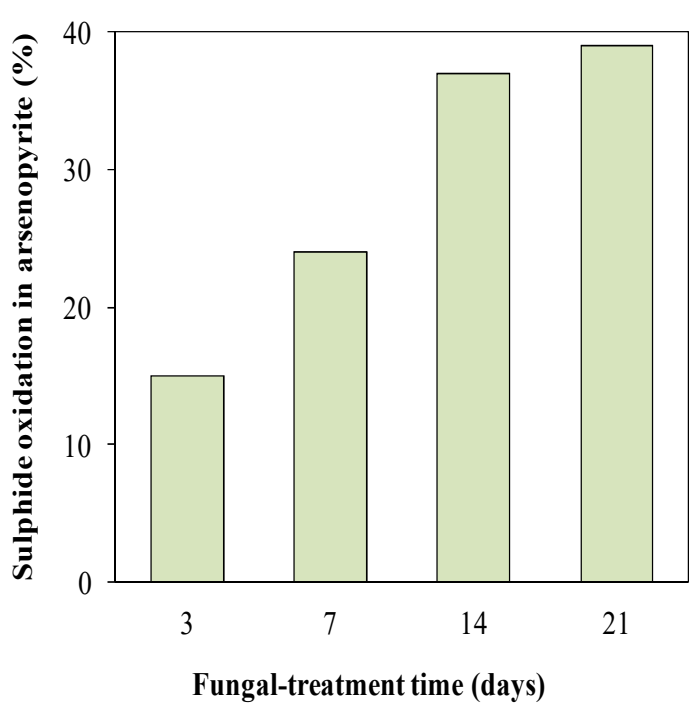

Fig. 8 Oxidation of Sulphide Sulphur in Arsenopyrite following Pretreatment with P. chrysosporium

Figs. 7 and 8 show time dependence of the sulphide transformation especially in the case of arsenopyrite. Pyrite realised about $10 \%$ transformation within 3 days of treatment, and this increased to about $16 \%$ in 7 days plateauing off at $18 \%$ in 21 days. In the case of arsenopyrite, there was about $15 \%$ transformation in 3 days, $24 \%$ in 7 days, $36 \%$ in 14 days and $39 \%$ in 21 days. Biotransformation in arsenopyrite was higher due to its less noble state. Relating the extent of fungaltransformation to the control experiments, it is clear from Fig. 9 that the transformation of sulphides were mainly due to the presence of the fungus, as more than 4 -fold oxidation $(400 \%)$ of sulphide sulphur was achieved.

X-ray diffraction studies of pyrite is presented in Fig. 10. The main sulphide peak occurs at $33 \mathrm{deg}$ on the 2-theta axis, and the figure shows that following fungal transformation, the peak decreased by more than $50 \%$, indicating a major degree of alteration. This implies a change in $\mathrm{J}$ factor of the sulphides from an undisturbed lattice value of 1 to about 0.5 following fungaltransformation. Since the sulphides used in this study were the pure forms containing 52\% and $20 \%$ sulphide sulphur respectively in pyrite and arsenopyrite, there is no doubt that a higher degree of transformation can be achieved when treating refractory gold ores and concentrates which usually contain less than 15\% sulphide sulphur (OsseoAsare et al., 1984; Ofori-Sarpong et al., 2013b).

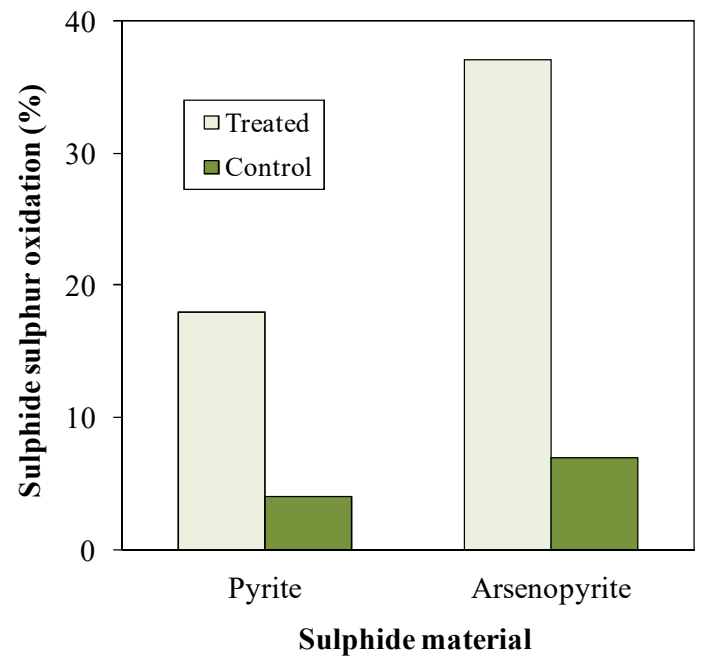

Fig. 9 The Exclusive Effect of $P$. chrysosporium on Biotransformation of Sulphides

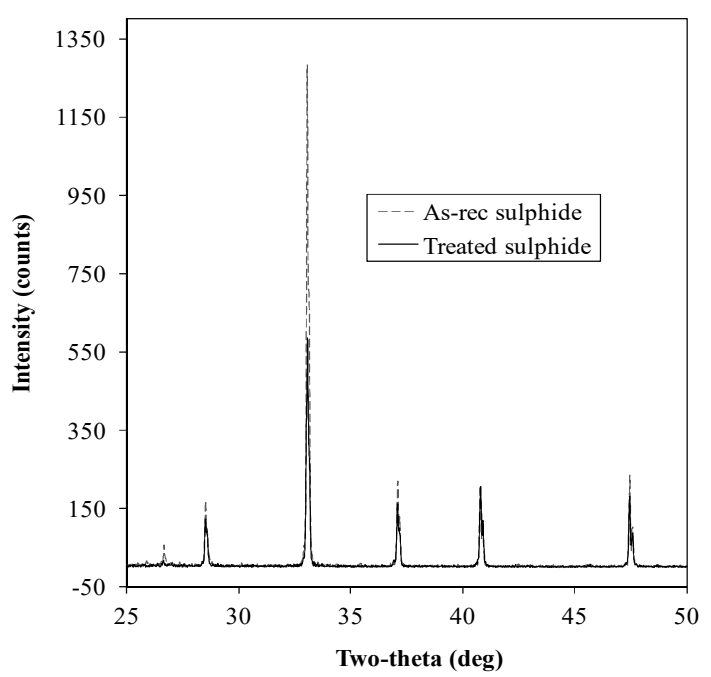

Fig. 10 X-ray Diffraction of Pyrite before and after Fungal-Treatment

\section{Conclusion}

This paper reports on an overview of the authors' research into the possibility of pretreating refractory gold ores using the fungus, $P$. chrysosporium. Coal of various ranks was used as surrogate for carbonaceous matter whereas pure pyrite and arsenopyrite were used to represent sulphides in refractory gold ores. The study revealed a reduction of more than $90 \%$ gold adsorption by anthracite coal, which has about 15 fold higher ability to adsorb aurocyanide than the other coals. The ability of anthracite to adsorb relatively higher levels of gold cyanide is due to the well developed graphitic structure which is important for aurocyanide adsorption. As a result of fungal treatment, there was disruption in the graphitc structure, and this accounted for the reduction in gold adsorption. 
In the case of the pure sulphides, there was about $18 \%$ and $39 \%$ transformation of pyrite and arsenopyrite respectively by fungal-treatment. Comparative studies using XRD revealed a change in J-factor of the sulphides from an undisturbed lattice value of 1 to about 0.5 following fungaltransformation. The findings suggest a higher degree of transformation when treating refractory gold ores and concentrates which usually contain less than $15 \%$ sulphide sulphur.

\section{Acknowledgements}

The authors express their profound gratitude to the Ghana Education Trust Fund and the University of Mines and Technology (UMaT) for financial assistance in carrying out this work.

\section{References}

Abotsi, G. M. K., Osseo-Asare, K. (1987), "Surface chemistry of carbonaceous gold ores. II. effects of organic additives on gold adsorption from cyanide solution", International Journal of Mineral Processing, Vol. 21, pp. 225-239.

Adam, A. S., Ofori-Sarpong, G. and Amankwah, R. K. (2017), "Assessing the challenges in the extraction of gold from bacterial-treated doublerefractory concentrate", In: Proceedings of the SME Annual Meeting, Feb. 19 - 22, 2017, Denver, CO, Preprint 17-014 (1-7).

Adams, M. D., Burger, A. M. (1998), "Characterization and blinding of carbonaceous preg-robbers in gold ores", Minerals Engineering, Vol. 11, Issue 10, pp. 919-927.

Afenya, P. M. (1991), "Treatment of carbonaceous refractory gold ores", Minerals Engineering, Vol. 4, Issues 7-11, pp. 1043-1055.

Amankwah, R. K., Yen, W. T. (2006), "Effect of carbonaceous characteristics on biodegradation and preg-robbing behavior", In: Proceedings of the 23rd International Mineral Processing Congress, Onal, G., Acarkan, N., Celik, M. S., Arslan, F., Atesok, G., Guney, A., Sirkecl, A. A., Yuce, A. E., Perek, K. T. (Eds.), Instanbul, pp. 1445-1451.

Amankwah, R. K., Yen, W. T. and Ramsay, J. (2005), "A two-stage bacterial pretreatment process for double refractory gold ores", Minerals Engineering, Vol. 18, pp. 103-108.

Antonijevic, M. M., Dimitrijevic, M. and Jankovic, Z. (1997), "Leaching of pyrite with hydrogen peroxide in sulphuric acid", Hydrometallurgy, Vol. 46, pp. 71-83.

Arriagada, F. J., Osseo-Asare, K. (1984), “Gold extraction from refractory ores: roasting behavior of pyrite and arsenopyrite", In: Precious Metals: Mining, Extraction and Processing, Kudryk, V., Corrigan, D. and Liang, W. W. (Eds.), The Metallurgical Society of AIME, Warrendale, PA, pp. $367-385$.
Bennett, J. C., Tributsch, H. (1978), "Bacterial leaching patterns on pyrite crystal-surfaces", Journal of Bacteriology, Vol. 134, pp. 310-317.

Berezowsky, R. M. G. S., Haines, A. K. and Weir, D. R. (1988), "The Sao Bento gold project pressure oxidation process development", In: 18th Annual meeting, Hydromet section of CIM, CIM, Edmonton, Alberta, pp. 1-24.

Boyle, R. W. (1979), "The Geochemistry of Gold and its Deposits", Canada Geological Survey Bulletin, p. 280.

Brierley, C. L. (1997), "Mining biotechnology: research to commercial development and beyond", In: Biomining: Theory, Microbes and Industrial Processes, Rawlings, D. E. (Ed.), Springer Verlag, Berlin, Germany, pp. 3-17.

Brierley, J. A., Kulpa, C. F. (1993), "Biometallurgical treatment of precious metal ores having refractory carbon content", US Patent, 5,244,493.

Bumpus, J. A., Aust, S. D. (1986), "Biodegradation of environmental pollutants by the white-rot fungus Phanerochaete chrysosporium: involvement of the lignin degrading system", BioEssay, Vol. 6, pp. 1143-1150.

Glenn, J. K., Morgan, M. A., Mayfield, M. B., Kuwahara, M. and Gold, M. H. (1983), "An extracellular $\mathrm{H}_{2} \mathrm{O}_{2}$-requiring enzyme preparation involved in lignin biodegradation by the white rot basidiomycete Phanerochaete chrysosporium", Biochemical and Biophysical Research Communications, Vol. 114, pp. 1077-1083.

Gonsalvesh, L., Marinov, S. P., Stefanova, Yurum, M. Y., Dumanli, A. G., Dinler-Doganay, G., Kolankaya, N., Sam, M., Carleer, R., Reggers, G., Thijssen, E. and Yperman, J. (2008), "Biodesulphurized subbituminous coal by different fungi and bacteria studied by reductive pyrolysis. Part 1: Initial coal", Fuel, Vol. 87, pp. 2533-2543.

Gordon, J. J. K. and Asiam, E. K. (2012), "Influence of mechano-chemical activation on biooxidation of auriferous sulphides", Hydrometallurgy, Vol. 115-116, pp. 77-83.

Guay, W. J. (1981), "The treatment of refractory gold ores containing carbonaceous material and sulphides", In: Gold and silver leaching: recovery and economics, Schlitt, W. J. Larson, W. C. and Hiskey, J. B. (Eds.) SME-AIME, Littleton, pp. 17-22.

Hackl, R. P. (1997), "Commercial applications of bacterial-mineral interactions", In BiologicalMineralogical Interactions, McIntosh, J. M. and Groat, L. A. (Eds.), Mineralogical Association of Canada, Ottawa, pp. 143-167.

Harneit, K., Goksel, A., Kock, D., Klock, J-H., Gehrke, T. and Sand, W. (2006), "Adhesion of metal sulphide surfaces by cells of Acidithiobacillus ferrooxidans, Acidithiobacillus thiooxidans and Leptospirillum ferrooxidans", Hydrometallurgy, Vol. 83, pp. 245-254. 
Hausen, D. M., Bucknam, C. H. (1985), "Study of preg robbing in the cyanidation of carbonaceous gold ores from Carlin, Nevada", In: Proceedings of the Second International Congress on Applied Mineralogy, Park, W. C., Hausen, D. M. and Hagni, R. D. (Eds.),AIME, Warrendale, PA, pp. 833-856.

Helm, M., Vaughan, J., Staunton, W.P., and Avraamides, J. (2009), "An investigation of the carbonaceous component of preg-robbing gold ores". WorldGold Conference 2009, The Southern African Institute of Mining and Metallurgy, 2009.

Holmes, D., Bonnefoy, V. (2006), "Insights into Iron and Sulphur Oxidation Mechanisms of Bioleaching Organisms", In Biomining, Rawlings, D. E., Johnson, B. D. (Eds), SpringerVerlag, Berlin, pp. 281-307.

Hutchins, S. E., Brierley, J. A. and Brierley, C. L. (1988), "Microbial pretreatment of refractory sulphide and carbonaceous ores improves the economics of gold recovery", Mining Engineering, Vol. 40, pp. 249-254.

Ibrado, A. S. and Fuerstenau, D.W. (1992), "Effect of the structure of carbon adsorbents on the adsorption of gold cyanide", Hydrometallurgy, Vol. 30, pp. 243-256.

Jennings, S. R., Dollhopf, D. J. and Inskeep, W. P. (2000), "Acid production from sulphide minerals using hydrogen peroxide weathering", Applied Geochemistry, Vol. 15, pp. 235-243.

Jones, W. G., Klauber, C. and Linge, H. G. (1989), "Fundamental aspects of gold cyanide adsorption on activated carbon", In: Gold Forum on Technology and Practices - 'World Gold '89', Bhappu, R. B., Handen, R. J. (Eds) SME, Littleton, Co, pp. 278-281.

Kersten, P. J. and Kirk, T. K. (1987), "Involvement of a new enzyme, glyoxal oxidase, in extracellular $\mathrm{H}_{2} \mathrm{O}_{2}$ production by Phanerochaete chrysosporium: synthesized in the absence of lignin in response to nitrogen starvation", Journal of Bacteriology, Vol. 135, pp. 790-797.

Komnitsas, C. and Pooley, F. D. (1989), "Mineralogical characteristics and treatment of refractory gold ores", Minerals Engineering, Vol. 2, Issue 4, 449-457.

Konadu, K. T., Sasaki, K., Kaneta, T., OforiSarpong, G. and Osseo-Asare, K. (2016) "BioModification of Carbonaceous Matters in Gold Ore: Model Experiments Using Powdered Activated Charcoal and Cell-Free Spent Medium of Phanerochaetechrysosporium", Hydrometallurgy,

http://dx.doi.org/10.1016/j.hydromet.2016.08.003

Liu, Q., Yang, H-y. and Tong, L-1 (2014), "Influence of Phanerachaete chrysosporium degradation and preg-robbing capacity of activated carbon", Trans. Nonferrous Met. Soc.China, pp. 1905-1911.

Madigan, M. T. and Martinko, J. M. (2006), Brock's Biology of Microorganisms, $11^{\text {th }} \mathrm{ed}$.,
Pearson Prentice Hall, Upper Saddle River, NJ, pp 469-472, 691-692.

Marsden, J. and House, I. (2006), The Chemistry of Gold Extraction, $2^{\text {nd }}$ ed., Society for Mining, Metallurgy and Exploration, Inc. Littleton, Colorado, pp 42-44, 111-126, 161-177, 191-193, 233-263, 297-333.

Martin, W. and Petersen, F. W. (2001), "Effect of operating conditions on the fungal decomposition of gold impregnated wood chips", Minerals Engineering, Vol. 14, pp. 405-410.

Nyavor, K. and Egiebor, N. O. (1992), "Application of pressure oxidation pretreatment to a double-refractory gold concentrate", CIM Bulletin, Vol. 84(956), pp. 84-90.

Ofori-Sarpong, G. and Osseo-Asare, K. (2013), "Preg-robbing of Gold from Cyanide and NonCyanide Complexes: Effect of Fungi Pretreatment of Carbonaceous Matter", International Journal of Mineral Processing, Vol. 119, pp. 27-33.

Ofori-Sarpong, G., Amankwah, R. K. and OsseoAsare, K. (2013a), "Reduction of Preg-Robbing by Biomodified Carbonaceous Matter-A Proposed Mechanism", Minerals Engineering, Vol. 42, pp. 29-35.

Ofori-Sarpong, G., Osseo-Asare, K. and Tien, M. (2011), "Fungal pretreatment of sulphides in refractory gold ores", Minerals Engineering, Vol. 24, pp. 499-504.

Ofori-Sarpong, G., Osseo-Asare, K., and Tien, M. (2013b),"Mycohydrometallurgy:

Biotransformation of Double Refractory Gold Ores by the Fungus, Phanerochaete chrysosporium", Hydrometallurgy, Vol. 137, pp. $38-44$.

Ofori-Sarpong, G., Tien, M. and Osseo-Asare, K. (2010), "Myco-hydrometallurgy: Coal model for potential reduction of preg-robbing capacity of carbonaceous gold ores using the fungus, Phanerochaete chrysosporium", Hydrometallurgy 102, 66-72.

Osseo-Asare, K., Afenya, P. M. and Abotsi, G. M. K. (1984), "Carbonaceous Matter in Gold Ores; Isolation, Characterization and Adsorption Behavior in Aurocyanide Solution", In: Precious Metals: Mining, Extraction and Processing, Kudryk, V., Corrigan, D. and Liang, W. W. (Eds.), The Metallurgical Society of AIME, Warrendale, PA, pp. 125-144.

Pyke, B. L., Johnston, R. F. and Brooks, P. (1999), "The characterisation and behaviour of carbonaceous material in a refractory gold bearing ore", Minerals Engineering, Vol. 12, pp. 851-862.

Ralph, J. P. and Catcheside, D. E. A. (1997), "Transformations of low-rank coal by Phanerochaete chrysosporium and other woodrot fungi”, Fuel Processing Technology, Vol. 52, pp. 79-93.

Rawlings, D. E. (1998), "Industrial practice and the biology of leaching of metals from ores", Journal 
of Industrial Microbiology and Biotechnology, Vol. 20, pp. 268-274

Sand, W., Gehrke, T., Hallmann, R. and Schippers, A. (1995), "Sulfur chemistry, biofilm, and the (in) direct attack mechanism - a critical evaluation of bacterial leaching", Applied Microbiology and Biotechnology, Vol. 43, pp. 961-966.

Silver, M. (1970), "Oxidation of elemental sulfur and sulfur compounds and $\mathrm{CO}_{2}$ fixation by Ferrobacillus ferrooxidans (Thiobacillus ferrooxidans)", Canadian Journal of Microbiology, Vol. 16, pp. 845-849.

Tien, M. and Kirk, T. K. (1984), "Lignin-degrading enzyme from Phanerochaete chrysosporium: purification, characterization and catalytic properties of a unique $\mathrm{H}_{2} \mathrm{O}_{2}$-requiring oxygennase", Proceedings of the National Academy of Sciences, Vol. 81, pp. 2280-2284.

Tunde, M. and Tien, M. (2000), "Oxidation mechanism of ligninolytic enzymes involved in the degradation of environmental pollutants", International Biodeterioration and Biodegradation, Vol. 46, pp. 51-59.

Van Krevelen, D. W. (1993), Coal: Typology-Physics-Chemistry-Constitution, 3rd ed., Elsevier, Amsterdam, $771 \mathrm{pp}$.

Vaughan, J. P. (2004), "The process mineralogy of gold: The classification of ore types", JOM, Metals and Materials Society, Vol. 56, pp. 46-48.

Yang, H. Y., Liu, Q., Song, X. L. and Dong, J. K. (2013), "Research status of carbonaceous matter in carbonaceous gold ores and bio-oxidation pretreatment", Trans. Nonferrous Met., Soc., China 23, pp. 3405-3411.

Yannopoulos, J. C. (1991), The Extractive Metallurgy of Gold, Van Nostrand Reinhold, New York, pp. 141-148.

Yen, W. T., Amankwah, R. K. and Choi, Y. (2008), "Microbial pre-treatment of double refractory gold ores", In: Young C. A, Taylor P. R., Anderson C. G. and Choi Y. (Eds.), Proceedings of the Sixth International Symposium, Hydrometallurgy '2008, Phoenix, USA. SME, Littleton, CO, 506-510.

\section{Authors}

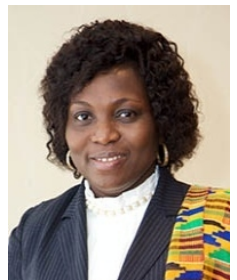

Grace Ofori-Sarpong is an Associate Professor of Minerals Engineering at the University of Mines and Technology, Tarkwa. She holds a PhD in Energy and Mineral Engineering from the Pennsylvania State University, an MSc in Environmental Resources Management and BSc in Metallurgical Engineering, both from the Kwame Nkrumah University of Science and Technology, KNUST, Kumasi, Ghana. Her areas of research interest include microbial-mineral interaction, water quality monitoring, acid mine drainage issues, microwaves in extractive metallurgy, bio-modification of recalcitrant organic matter and small-scale gold mining. She is a member of the Society for Mining, Metallurgy and Exploration Engineers (SME), Society of Petroleum Engineers (SPE), Graduate Women in Science (GWIS) and the West African Institute of Mining, Metallurgy and Petroleum (WAIMM).

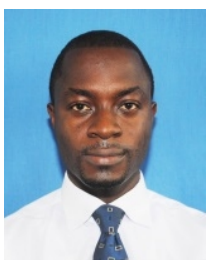

D. K. Adjei is a Metallurgical Engineer at Gold Coast Refinery, Accra. He holds BSc. degree in Minerals Engineering and a Certificate of Proficiency in Safety Management from the University of Mines and Technology, Tarkwa. His research work covers small-scale gold mining and processing, environmental safety and biohydrometallurgy.

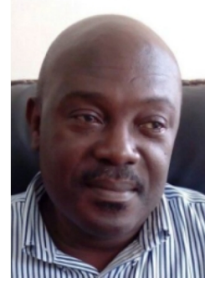

Richard K Amankwah is a Professor of Minerals Engineering at the University of Mines and Technology (UMaT), Tarkwa, Ghana. He holds a PhD degree in Mining Engineering from Queen's University, Canada, and MPhil and BSc in Metallurgical Engineering from the Kwame Nkrumah University of Science and Technology, KNUST, Kumasi, Ghana. His research interests include gold beneficiation, water quality management, microwave processing of minerals, small-scale mining, medical geology, microbial mineral recovery and environmental biotechnology. $\mathrm{He}$ is a Fellow of the West African Institute of Mining, Metallurgy and Petroleum (WAIMM), a member of the Ghana Institution of Engineers (GhIE) and Society for Mining, Metallurgy and Exploration Engineers (SME). 